\title{
Molecular evidence of polyphyletism in the plant genus Carum L. (Apiaceae)
}

\author{
Alessio Papini, Francesca Banci and Enio Nardi \\ Department of Plant Biology, University of Florence, Firenze, Italy.
}

\begin{abstract}
An analysis of internal transcribed spacer (ITS) DNA sequences of the four species of Carum L. (Apiaceae) known in Italy revealed that this genus is polyphyletic. Maximum parsimony with bootstrap resampling, maximum likelihood and Bayesian inference analyses resulted in three distinct clades: Carum carvi L. clustered within tribe Careae Baill. (former Aegopodium clade); Hellenocarum multiflorum (= Carum multiflorum), Carum heldreichii and Carum appuanum clustered within the tribe Pyramidoptereae Boiss.; and $H$. multiflorum and $C$. heldreichii formed a well supported clade. Since the sister group of $H$. multiflorum and $C$. heldreichii was Bunium elegans the autonomy of Hellenocarum from Carum is confirmed by our study. We also found that $C$. appuanum clustered separately from the other Carum species, with the closest related species appearing to be Scaligeria moreana but this still had few morphological similarities with $C$. appuanum.
\end{abstract}

Key words: Apiaceae, Carum, Hellenocarum, ITS, phylogeny.

Received: November 26, 2006; Accepted: February 2, 2007.

Evolutionary relationships among genera of Apiaceae, subfamily Apioideae, have been particularly difficult to resolve (Katz-Downie et al., 1999). In the last years many researchers have worked on this group, often finding high incongruence between molecular data and traditional taxonomic schemes. Nevertheless, the taxonomic treatments used in floras and monographs are still often derived from that proposed by Drude (1898). Recent cladistic analyses of molecular data supported the hypothesis that many of Drude's tribal and subtribal taxa are unnatural (Downie and Katz-Downie, 1996; Downie et al., 1998; Kondo et al., 1996; Valiejo-Roman et al., 1998; Downie et al., 2000a; Downie et al., 2000b).

The most used molecular markers in the Apioideae and many other angiosperms (Baldwin et al., 1995) have been the internal transcribed spacer (ITS) region of nuclear rDNA. In order to establish the phylogenetic position of the Italian species of Carum L. (representing most European species) we analyzed the nucleotide sequences of the ITS region as molecular markers.

The genus Carum is an important genus of the family Apiaceae, and contains about 20-30 species from Europe, North Africa and Asia (Hiroe, 1979; Pimenov and Leonov, 1993). Five species are present in Europe (Tutin, 1968), four of them in Italy (Pignatti, 1982). The best known species of this genus is Carum carvi L. (caraway or Persian

Send correspondence to Alessio Papini. Department of Plant Biology, University of Florence, Via La Pira 4, 50121 Firenze, Italy. E-mail alessio.papini@tin.it. cumin), which is one of the oldest herbs known (Nemeth, 1998). It is used traditionally as a condiment, oil and drug and, more recently, for the extraction of carvone, a compound which inhibits sprouting in potatoes (Langenberger and Davis, 2002b; Nemeth, 1998). Caraway is also important for honey production ( 70 to $134 \mathrm{~kg} \mathrm{ha}^{-1}$ ) from Canadian behives (Langenberger and Davis, 2002a) and new medicinal uses such as anti-hyperglycemic potential have recently been reported (Eddouks et al., 2004).

For the purpose of our analysis we adopted the taxonomic treatment by Pignatti (1982) with the exception of Hellenocarum multiflorum (Sibth. \& Sm.) Wolff, treated after Tan and Sorger (1986) with C. carvi L., Carum appuanum (Viv.) Grande, Carum heldreichii Boiss. H. multiflorum (Sibth. \& Sm.) Wolff (Carum multiflorum (Sibth. \& Sm.) Boiss. After Pignatti (1982)). Pignatti (1982) considered C. heldreichii, described by Boissier for Greece as a species enclosing the populations described in Italy with the names Carum flexuosum (Ten.) Nym. (nom. illeg.) and Carum carvifolium (DC.) Arcang. (nom. illeg.).

Genus Hellenocarum was originally described by Wolff (1927) and after Tan and Sorger (1986) it is weakly delimited from Carum and might perhaps be better recognized at subgeneric rank. The verification of this hypothesis was one of the aims of this paper.

The three species of Carum (besides C. carvi) investigated by us were quite rare species and with areal disjunctions (Italy-Balkans). The Italian populations of $H$. multiflorum have been separated as H. multiflorum (Sibth. $\&$ Sm.) Wolff ssp. multiflorum. Also C. appuanum (" $C$. 
apuanum" in Pignatti, 1982) was split in more subspecies, including one Italian ssp. (appuana) (Bechi and Garbari, 1994).

Silica gel preserved samples of leaf tissue were obtained directly in the field for Carum appuanum (Monte Matanna, Apuan Alps, 12 August 2003) and C. heldreichii (Scaffaiolo Lake, Tuscan Appennines 6 August 2003) while a sample of $H$. multiflorum coming from a population in Gravina di Laterza, southern Italy, was collected on 4 July 2002 and sent to us by the Botanical Garden of Lecce.

Genomic DNA was isolated using a modified Doyle and Doyle (1990) cetyltrimethylammonium bromide (CTAB) extraction protocol in which grinding the tissue in sea-sand and 70\% (v/v) isopropanol substituted for the RNase step. Approximately $40 \mathrm{mg}$ of leaf tissue were used for each extraction. The DNA concentrations were estimated by gel electrophoresis on $1 \%(\mathrm{w} / \mathrm{v})$ agarose gel. For each sample the PCR reactions were carried out with about $10 \mathrm{ng}$ of genomic DNA in a final volume of $50 \mu \mathrm{L}$ containing $1.25 \mathrm{U}$ of Taq polymerase (Takara) and the $18 \mathrm{~S}$ sequence primer (5'-CGTAACAAGGTTTCCGTAG) and 26S primer (5'-AGTCCGCCCTGATGGGCGA). The thermal cycling profile consisted of 35 cycles of $1 \mathrm{~min}$ at $94{ }^{\circ} \mathrm{C}, 1 \mathrm{~min}$ at $50{ }^{\circ} \mathrm{C}$ and $2 \mathrm{~min}$ at $72^{\circ} \mathrm{C}$ followed a final extension of $7 \mathrm{~min}$ at $72{ }^{\circ} \mathrm{C}$. Clear cut single-banded fragments were separated on $1 \%(\mathrm{w} / \mathrm{v})$ agarose gels. The resulting single-banded amplification products were purified and directly sequenced in both directions using the primers described above and a Perkin Elmer automated sequencer model 310 at the Center for Biotechnological Services (CIBIACI) of the University of Florence. We used asymmetrical PCR cycle sequencing and the BigDye Terminator Ready Reaction Kit (Applied Biosystems).

For sequence and phylogenetic analysis the resulting ITS sequences were visualized and checked by eye with the CHROMAS 1.43 software (C. McCarthy, School of Biomolecular and Biomedical Sciences, Brisbane, Australia). We performed a BLAST (Altschul et al., 1997) search to exclude the sequencing of any contaminant organism. The new ITS sequences produced during our investigation were deposited in the GenBank, the accession numbers being given in Table 1. Other GenBank sequences were chosen to sample for all the main clades of Umbellifers indicated in previous molecular studies (in particular Katz-Downie et al., 1999). We used as outgroups Oenanthe pimpinelloides and Ligusticum porteri and not some representatives of the Apioid superclade because one of the aims of the study was to test the relationship between Careae and Pyramidoptereae with respect to other groups. Moreover it was difficult a priori to be sure that some Carum representatives would nest outside Pyramidoptereae and Careae. In a previous analysis of the Apioideae subfamily by Katz-Downie et al. (1999), Pyramidoptereae and Careae clustered together with $67 \%$ bootstrap support while less than $50 \%$ bootstrap support supported the clade formed by the rest of the
"Apiod Superclade". A maximum parsimony analysis of Careae+Pyramidoptereae with two representatives of the Apioid superclade as outgroups (data not shown) yielded a strict consensus tree with the same topology as those obtained in this analysis. Optimal multiple alignment was obtained with CLUSTALW 1.81 (Thompson et al., 1994) and checked by eye. Parsimony analysis was performed with PAUP 4.0b1 (Swofford, 1998) for MS DOS operating system. All characters were weighted equally, and character state transitions were treated as unordered. Gaps were treated after Simmons \& Ochoterena (2000) and coded with Simple Gap Coding using the Gapcoder software (Young \& Healy, 2003). This process codes indels as separate characters in a data matrix, which is then considered along with the DNA base characters in the phylogenetic analysis. The maximum parsimony analysis was done with 100 replicated heuristic searches, using random stepwise addition of taxa, tree bisection reconnection (TBR) branch swapping, and MULTREES in effect. Bootstrap (Felsenstein, 1985) resampling (BS in the trees description) was performed using TBR branch-swapping with ten random taxon entries per replicate and the multrees option in effect with 100 replicates.

A maximum likelihood (Felsenstein, 1981) search approach was carried out using the MrMODELTEST 2.0 program (Nylander, 2004) to evaluate the best likelihood model as settings in a maximum likelihood (ML) phylogenetic analysis in PAUP and for Bayesian Inference with the MrBayes 3.4b4 program (Huelsenbeck, 2001; Huelsenbeck et al., 2002). The maximum likelihood heuristic search was done with 10 random additions and TBR branch swapping, and the command ADDSEQ = ASIS with PAUP. The Bayesian analysis was done using the sequence evolution model indicated by the MrMODELTEST program based on the Akaike information criterion (Akaike, 1974). The Bayesian phylogenetic analysis was used for assessing the robustness of tree topology and the support for clades. The posterior probability of the phylogenetic model was estimated using Markov chain Monte Carlo (MCMC) sampling with the Metropolis-Hastings-Green algorithm. Four chains were run, three heated and one cold, for $10^{6}$ generations and sampled every 100 generations. Following the analysis, the posterior probabilities were checked in the output of Mrbayes to estimate the number of trees that should be discarded as "burn-in". Stationary values were reached at approximately 20,000 generations, so the first 200 trees, or "burn-in" period of the chain, were discarded. Phylogenetic inference is therefore based on those trees sampled after generation 20,000. After the "burn-in" trees were removed from the data set, the remaining trees were used to produce a $50 \%$ majority-rule consensus tree (with PAUP) in which the percentage support was considered equivalent to Bayesian posterior probabilities. To test the significance of the difference of less parsimonious trees with respect to the most parsimonious solution, the 
Table 1 - Apiaceae accessions used in our internal transcribed spacer (ITS) sequence study. When a single GenBank (GBAN) accession number is indicated, the whole ITS1-5.8S-ITS2 is intended, otherwise the first accession correspond to ITS1 and the second to ITS2. Species sequenced by the authors are underlined. Herbarium samples are available from the authors.

\begin{tabular}{|c|c|c|}
\hline Genus species and affiliation & Reference & ITS source \\
\hline Aegokeras caespitosa (Sibth. \& Sm.) Raf. & Downie et al., 1998 & GBAN U78379, GBAN U78439 \\
\hline Aegopodium alpestre Ledeb. & Downie et al., 1998 & GBAN U78376, GBAN U78436 \\
\hline Aegopodium podagraria $\mathrm{L}$. & Downie \& Katz-Downie, 1996 & GBAN U30536, GBAN U30537 \\
\hline Angelica archangelica $\mathrm{L}$. & Downie \& Katz-Downie, 1996 & GBAN U30576, GBAN U30577 \\
\hline Apium graveolens $\mathrm{L}$. & Downie et al., 1998 & GBAN U30552, GBAN U30553 \\
\hline Arracacia brandegei J. M. Coult. \& Rose & Downie \& Katz-Downie, 1996 & GBAN U30570, GBAN U30571 \\
\hline Bunium elegans (Fenzl) Freyn & Downie et al., 2000 & GBAN AF073543, GBAN AF073544 \\
\hline Capnophyllum dichotomum Lag. & Downie et al., 1998 & GBAN U78390, GBAN U78391 \\
\hline Carum appuanum (Viv.) Grande & Monte Matanna, Alpi Apuane, Tuscany & GBAN AY840984, GBAN AY840985 \\
\hline Carum carvi L. (a) & Valiejo-Roman et al., 1998 & GBAN AF077878 \\
\hline Carum carvi L. (b) & Downie et al., 1998 & GBAN U78377, GBAN U78437 \\
\hline Carum heldreichii Boiss. & Lago Scaffaiolo, Appennines, Tuscany & GBAN AY840988, GBAN AY840989 \\
\hline $\begin{array}{l}\text { Carum multiflorum (Sibth. \& Sm.) Boiss. }= \\
\text { Hellenocarum multiflorum (Sibth. \& Sm.) Wolff }\end{array}$ & Gravina di Laterza (Taranto), South-East Italy & GBAN AY840986, GBAN AY840987 \\
\hline Chamaesciadium acaule C.A. Meyer & Mt. Aragats, Armenia & GBAN AY957495, GBAN AY957496 \\
\hline Ciclospermum leptophyllum (Pers.) Sprague & Downie et al., 2002 & GBAN AF358471, GBAN AF358538 \\
\hline Cnidium silaedium Fiori \& Paol. & Downie et al., 1998 & GBAN U78407, GBAN U78467 \\
\hline Coriandrum sativum $\mathrm{L}$. & Downie \& Katz-Downie, 1996 & GBAN U30586, GBAN U30587 \\
\hline Crithmum maritimum $\mathrm{L}$. & Downie \& Katz-Downie, 1996 & GBAN U30540, GBAN U30541 \\
\hline $\begin{array}{l}\text { Elaeosticta allioides (Regel \& Schmalh.) E.V. } \\
\text { Klyuikov, M.G. Pimenov \& V.N. Tikhom. }\end{array}$ & Downie et al., 2000 & GBAN AF73547, GBAN AF73548 \\
\hline Falcaria vulgaris Bernh. & Downie et al., 1998 & GBAN U78378, GBAN U78438 \\
\hline Ferula assa-foetida $\mathrm{L}$. & Downie et al., 1998 & GBAN U78391, GBAN U78451 \\
\hline Foeniculum vulgare Mill. & Downie et al., 1998 & GBAN U78385, GBAN U78445 \\
\hline Fuernrohria setifoliaK. Koch & Katz-Downie et al., 1999 & GBAN AF008633, GBAN AF009112 \\
\hline Grammosciadium daucoides DC. & Downie et al., 2000 & GBAN AF073559, GBAN AF073560 \\
\hline Grammosciadium macrodon Boiss. & Downie et al., 2000 & GBAN AF073553, GBAN AF073554 \\
\hline Grammosciadium platycarpum Boiss. \& Hausskn. & Downie et al., 2000 & GBAN AF073551, GBAN AF073552 \\
\hline Grammosciadium pterocarpum Boiss. & Downie et al., 2000 & GBAN AF073557, GBAN AF073558 \\
\hline Grammosciadium scabridum Boiss. & Downie et al., 2000 & GBAN AF073555, GBAN AF073556 \\
\hline Heracleum sphondylium $\mathrm{L}$. & Downie \& Katz-Downie, 1996 & GBAN U30544, GBAN U30544 \\
\hline Lagoecia cuminoides L. & Valiejo-Roman et al., 2002 & GBAN AF337179, GBAN AF337187 \\
\hline Levisticum officinale Koch & Downie et al., 1998 & GBAN U78389, GBAN U78449 \\
\hline Ligusticum porteri J. M. Coult. \& Rose & Downie et al., 1998 & GBAN U78375, GBAN U78435 \\
\hline Oedibasis platycarpa(Lipsky) Koso-Pol. & Katz-Downie et al., 1999 & GBAN AF008632, GBAN AF009106 \\
\hline Oenanthe pimpinelloides $\mathrm{L}$. & Downie et al., 1998 & GBAN U78371, GBAN U78431 \\
\hline Pastinaca sativa $\mathrm{L}$. & Downie et al., 1998 & GBAN U30546, GBAN U30547 \\
\hline Peucedanum coriaceum Reichenb. & Spalik et al., 2004 & GBAN AF495824, GBAN AF495825 \\
\hline Pimpinella peregrina $\mathrm{L}$. & Downie et al., 1998 & GBAN U30592, GBAN U30593 \\
\hline Prangos pabularia Lindl. & Downie et al., 1998 & GBAN U78409, GBAN U78469 \\
\hline Pycnocycla aucherana Boiss. & Downie et al., 2000 & GBAN AF073533, GBAN AF073534 \\
\hline Pyramidoptera cabulica Boiss. & Katz-Downie et al., 1999 & GBAN AF008631, GBAN AF009110 \\
\hline Rhabdosciadium aucheri Boiss. & Downie et al., 2000 & GBAN AF073549, GBAN AF073550 \\
\hline Rhodosciadium argutum (Rose) Mathias \& Constance & Downie \& Katz-Downie, 1996 & GBAN U30566, GBAN U30567 \\
\hline Scaligeria moreana Engstrand & Downie et al., 2000 & GBAN AF73545, GBAN AF73546 \\
\hline Seseli krylovii (V.Tichom.) Pimenov \& Sdobnina & Downie et al., 1998 & GBAN U78402, GBAN U78462 \\
\hline Smyrniopsis aucheri Boiss. & Downie et al., 1998 & GBAN U78393, GBAN U78453 \\
\hline Trachyspermum aethusifolium Chiov. & Downie et al., 2000b & GBAN AF164845, GBAN AF164870 \\
\hline Trachyspermum ammi (L.) Sprague & Downie et al., 1998 & GBAN U78380, GBAN U78440 \\
\hline
\end{tabular}


Papini et al.

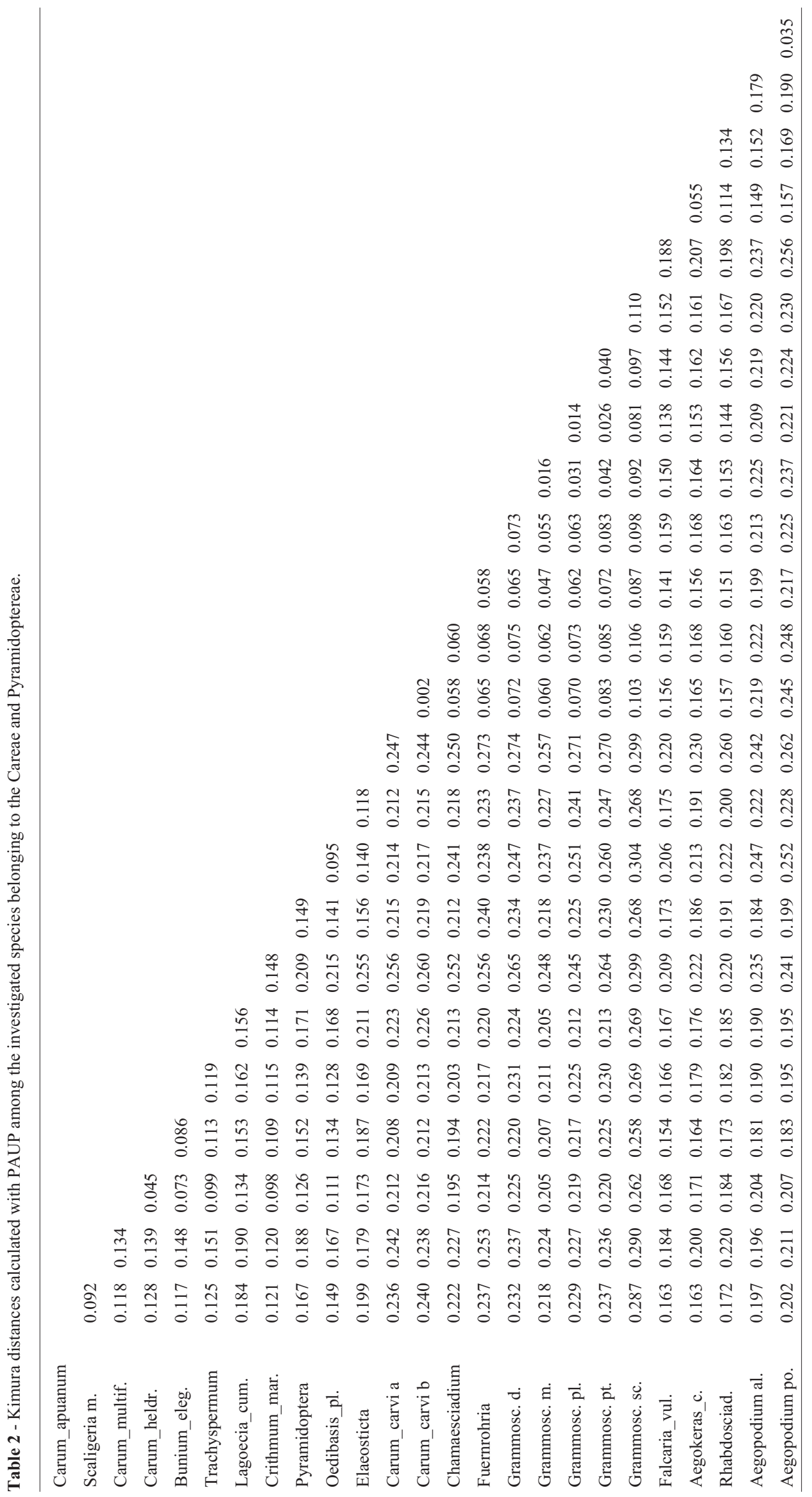


Templeton test (Templeton, 1983) was used as implemented in PAUP. Also distances among the investigated species and those useful for clarifying the phylogenetic relationships were calculated with PAUP with Kimura's settings (Kimura, 1980) and reported in Table 2.

The total alignment (ITS1+ITS2) was 469 bp long, plus 69 characters derived from indels coding (simple gaps coding). The Maximum Parsimony analysis showed that 131 characters were constant, 85 parsimony uninformative and 253 parsimony informative. Of the 69 indels-derived characters 45 were parsimony uninformative and 24 parsimony informative. The ITS1 length was $214 \mathrm{bp}$ in $H$. multiflorum, C. appuanum, and C. heldreichii while it reached $215 \mathrm{bp}$ in the two C. carvi accessions. The ITS2 was 215 bp long in C. appuanum, 219 in C. heldreichii and 220 in H. multiflorum, while it reached $223 \mathrm{bp}$ in the two accessions of $C$. carvi.

The MrModel test indicated as best fitting model for sequence evolution in the investigated data set the SYM $+\mathrm{I}+\mathrm{G}$ model with the following PAUP settings: Lset Base $=$ equal; Nst $=6$; Rmat $=\left(\begin{array}{l}0.84141 .97511 .5984 \\ 0.5398\end{array}\right.$ 0.5398 5.9200); Rates = gamma; Shape $=1.1658$; Pinvar $=0.0864$. We also used the indels data coded as simple gaps with the maximum parsimony analysis. The result was 180 maximum parsimony trees 1359 steps long, $\mathrm{CI}=0.480$ and $\mathrm{RI}=0.671$. The analysis without indels produced only 40 maximum parsimony trees 1273 steps long and with $\mathrm{CI}=0.458$ and $\mathrm{RI}=0.641$.

The maximum likelihood tree (score 6522.005) is shown in Figure 1, with Bayesian support above branches. The maximum likelihood tree and the Bayesian tree (majority rule consensus tree of the trees produced by the Bayesian analysis omitting the "burn in" trees) were concordant for the position of the investigated Carum and Hellenocarum species. A strict consensus tree of the maximum parsimony trees (indels analysis) with bootstrap support (BS) above branches is given in Figure 2. All the used phylogenetic methods were concordant about the position of the investigated Carum species.

We used the tribal nomenclature after Downie et al. (2001) particularly for the Careae Baill. and Pyramidoptereae Boiss. tribes, previously called (Downie et al., 1998) the Aegopodium group the Crithmum group respectively.

In our analysis Careae and Pyramidoptereae formed together a monophyletic group both with maximum parsimony and with maximum likelihood criterion, with $84 \%$ bootstrapping and 99\% Bayesian Support. Also two deletions in positions 56 and 180 (both one bp) characterized this clade.

The two C. carvi accessions clustered together with $100 \%$ bootstrap and Bayesian support and were nested in the Careae tribe, this tribe being supported by $91 \%$ bootstrapping and $100 \%$ Bayesian support and a one bp insertion at position 199. The closest relative of C. carvi was not determinable with parsimony because of polytomy in the

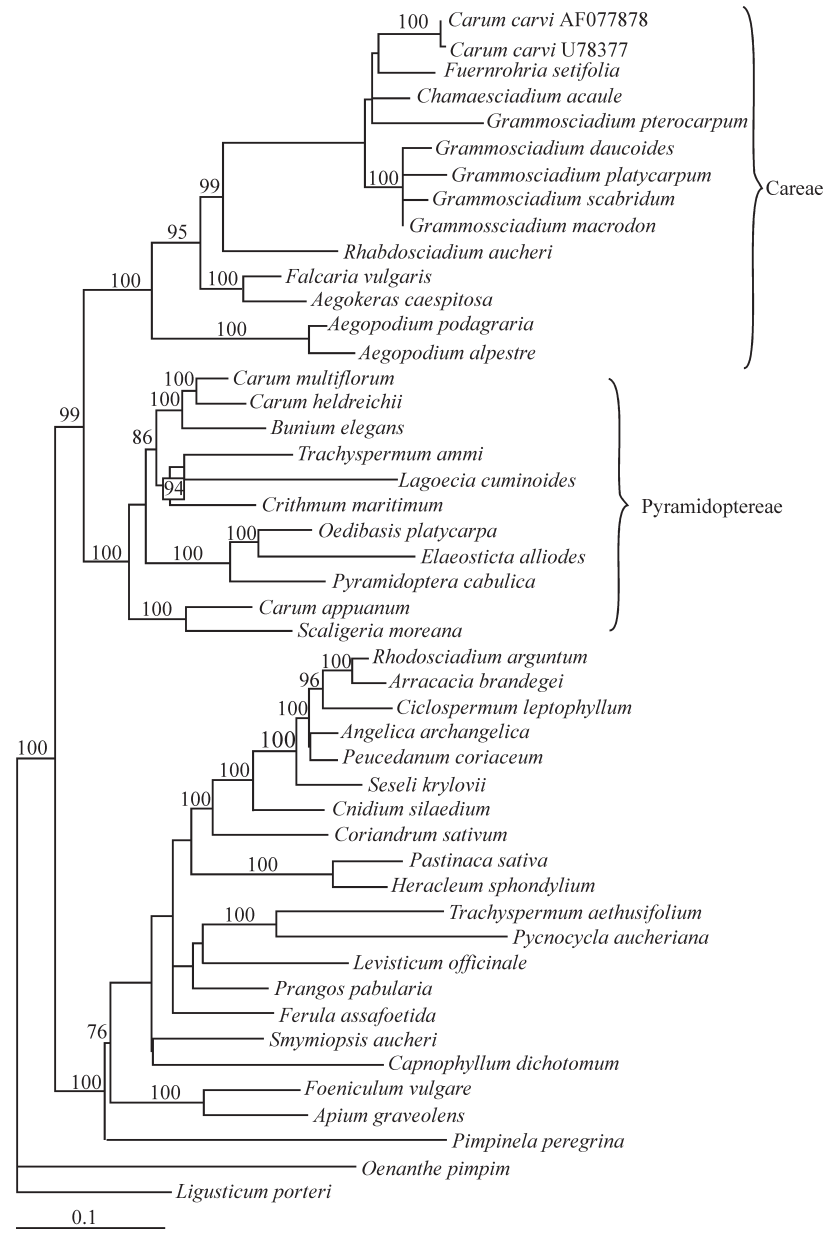

Figure 1 - Maximum likelihood tree with Bayesian support reported above branches.

consensus tree, while maximum likelihood tentatively identified the closest $C$. carvi relative as Fuernrohria setifolia.

We placed $C$. appuanum, $C$. heldreichii and $H$. multiflorum resulted in the Pyramidoptereae tribe, monophyly of this tribe being supported by $91 \%$ bootstrap support and $100 \%$ Bayesian support plus a deletion at position 270-276. The species H. multiflorum and C. heldreichii clustered with $96 \%$ bootstrap support and $100 \%$ Bayesian support. A 384-386 deletion was common to this tribe and to the Aegopodium. In the genus Aegopodium very variable chromosome counts are known, ranging from $2 \mathrm{n}=21-22$ to 44 in Aegopodium podagraria (Stepanov and Muratova, 1995) and from $2 \mathrm{n}=50$ to $2 \mathrm{n}=88$ in Aegopodium alpestre (Vasil'eva et al., 1994). The position of this genus is of interest since it belonged to the Careae on the basis of the phylogenetic analysis but shared a common insertion with the Pyramidoptereae tribe.

The sister group of Scaligeria moreana was $C$. appuanum with $92 \%$ bootstrap support and 100\% Bayesian support. 


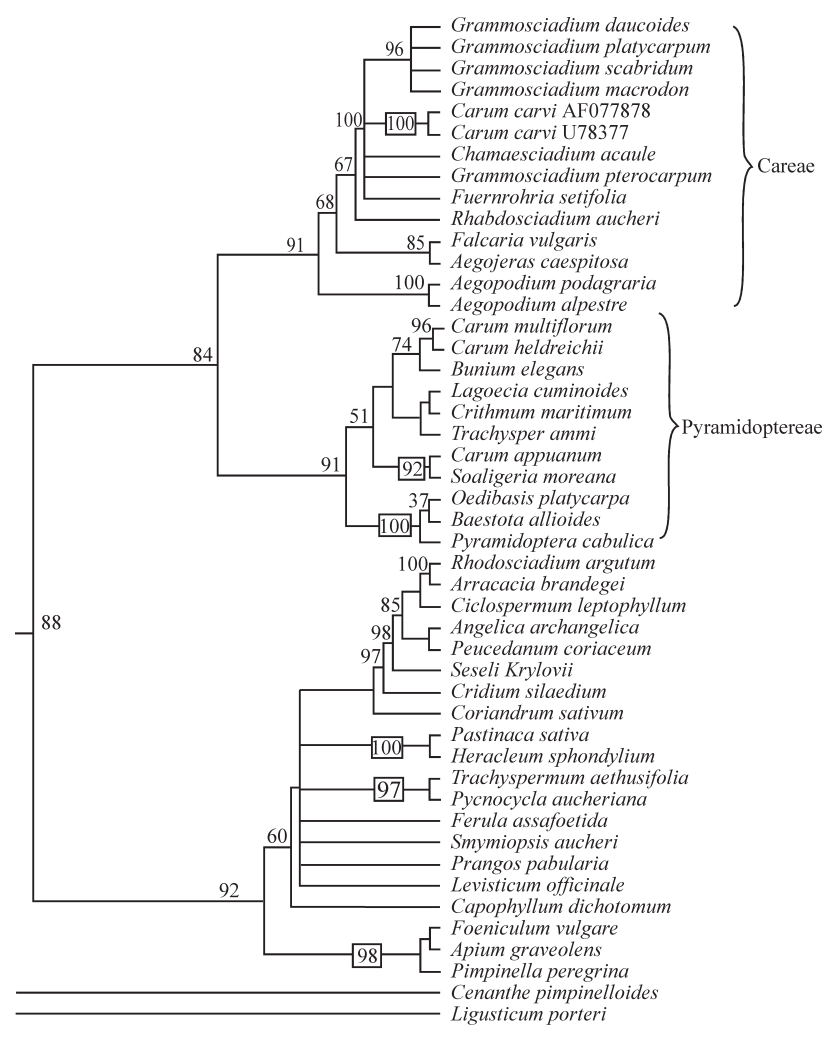

Figure 2 - Strict consensus tree of the 180 maximum parsimony trees (analysis with indels) with bootstrap support above branches.

The alternative phylogenetic hypothesis tested with the Templeton test were either that all Carum species grouped together or all Carum species in the Pyramidoptereae tribe grouped together. The hypothesis that all Carum species grouped together was rejected by our data because the resulting tree was 1477 steps long (118 more than the maximum parsimony tree). Both alternative hypotheses were significantly different after the Templeton test. These results, based on the phylogenetic analyses executed with different criteria on all the four species of the genus Carum L. (Apiaceae) presently recognized in Italy revealed that Carum is polyphyletic. Maximum parsimony with bootstrap resampling and maximum likelihood analysis and Bayesian inference analyses agreed in indicating three distinct clades for this genus. Kimura's distances indicated the same result. The conflicts in taxonomic treatment of Apiaceae between traditional treatments (Drude, 1898 and derived treatments) and molecular data has been quite common in the recent literature. For instance Downie et al. (2000b), showed that of 16 genera of which more than one species was examined, 11 were not monophyletic. Therefore the polyphyly of Carum L. is a new finding but not particularly surprising in the context of most recent phylogenetic analyses of the Apiaceae.

The type species of the genus, Carum carvi L., clustered within the Careae Baill. tribe (also called the Aegopodium clade after Downie et al., 2001), as previously observed by other authors. We also found that $C$. heldreichii, C. appuanum and $H$. multiflorum clustered within the Pyramidoptereae Boiss. tribe (the Crithmum group in Downie et al., 2001). The first two species formed a well supported clade with $96 \%$ bootstrapping and $100 \%$ Bayesian support. The autonomy of the genus Hellenocarum in relation to Carum is confirmed and enforced. Further sampling in Bunium and allied genera are necessary to ascertain if $C$. heldreichii is to be assigned to Hellenocarum or rather to consider both $H$. multiflorum and $C$. heldreichii as belonging to the genus Bunium with which (at least with Bunium elegans) these two species formed a clade supported by $74 \%$ bootstrapping and 100\% Bayesian support and a common insertion at position 461-462.

The chromosome number in H. multiflorum is $2 \mathrm{n}=20$ (personal observation by the authors and Brullo et al., 1995) and the same number (Favarger, 1973, under Carum carvifolium) has been found in Italy for C. heldreichii. Vasil'eva et al. (1985) found $2 \mathrm{n}=17,18$ in Bunium elegans, but other Bunium species such as $B$. bulbocastanum (Verlaque and Filosa, 1992) and $B$. cylindricum (Sheidai et al., 1996) proved to have the $2 \mathrm{n}=20$ as seen in Hellenocarum. The genus Bunium shows very variable chromosome numbers along a descending dysploidy line starting from $2 \mathrm{n}=22$ to $2 \mathrm{n}=12$ (Vasil'eva et al., 1985). After Vasil'eva et al. (1985) B. elegans belongs to a group formed also by Bunium simplex and Bunium paucifolium, the chromosome number $2 \mathrm{n}=18$ found in $B$. elegans and $B$. simplex would have arisen by dysploidy starting from the $2 \mathrm{n}=20$ found in $B$. paucifolium. This opinion on the origin of chromosome numbers in Bunium supports or, at least, does not contradict the molecular data in indicating that $H$. multiflorum and $C$. heldreichii may be close at least to some species belonging to the genus Bunium.

The second test with $C$. appuanum, C. heldreichii, $H$. multiflorum grouped together resulted in a 1378 steps tree (19 more than the maximum parsimony tree) and a significant difference after the Templeton test. The position of Carum appuanum was different from all the other Carum species considered here, with the closest species related to C. appuanum appearing to be Scaligeria moreana.

After Bechi et al. (1997) and Garbari (1970) C. appuanum has $2 \mathrm{n}=22$ chromosomes while in the genus Scaligeria only the chromosome number of Scaligeria stewartiana is known: $2 \mathrm{n}=20-24$ (Kour et al., 1992). Other species of the tribe Pyramidoptereae having chromosome numbers ranging from $2 \mathrm{n}=16$ in Lagoecia cuminoides (Baltisberger, 1991) to $2 \mathrm{n}=18$ in Trachyspermum ammi (Sehgal and Abbas, 1994) and 2n= 20 in Crithmum maritimum (Ruiz de Clavijo, 1990). For the genus Elaeosticta, a chromosome count $2 \mathrm{n}=22$ was found in Elaeosticta paniculata (Vasil'eva et al., 1993) and Elaeosticta glaucescens (Nazarova and Ghukasyan, 2004). The taxonomic position of Carum appuanum needs revi- 
sion since it clustered away from all the other Carum species but together with Scaligeria moreana. After a preliminary observation of samples of the genus Scaligeria in the Herbarium Centrale Italicum (in Florence, Italy) and descriptions in most recent floras morphological features do not appear to indicate a sufficient similarity to assert that these two species should belong to the same genus, hence Carum appuanum might need a new autonomous generic status on the basis of the ITS data. In conclusion certainly C. appuanum does not belong to Carum L. s. s. but further analyses with molecular and morphological data in Scaligeria and other Pyramidoptereae genera are necessary to propose a new taxonomic position for this species.

As shown in recent reviews (Alvarez and Wendel, 2003) caution is necessary in studying phylogeny with ITS data. A wide sampling of sequences of Apiaceae is available on the GenBank from previous studies. Possible limitations to the present study might also arise from the incomplete sampling in the genus Carum and other closely allied genera that could possibly reduce the resolution of the phylogenetic inference.

In the Careae tribe chromosome counts indicated $2 \mathrm{n}=20$ for C. carvi (Loeve and Loeve, 1982) and the closely related Grammosciadium daucoides, Grammosciadium platycarpum and Chamaesciadium acaule (Nazarova and Ghukasyan, 2004), 2n = 22 for Fuernrohria setifolia (Daushkevich et al, 1991) and Falcaria vulgaris (Kiehn et $a l, 2000)$. The closest relative to the important crop Carum carvi should hence be searched for among these genera.

\section{Acknowledgments}

The authors thank Gabriele Tani and Pietro Di Falco for their help in preparing mericarp sections and an anonymous reviewer for his help in improving the discussion of our results.

\section{Abbreviations}

$\mathrm{CI}=$ Consistency Index.

$\mathrm{RI}=$ Retention Index.

$\mathrm{PCR}=$ Polymerase Chain reaction.

\section{References}

Akaike H (1974) A new look at the statistical model identification. IEEE Trans Autom Contr 19:716-723.

Altschul SF, Madden TL, Schäffer AA, Zhang J, Zhang Z, Miller W and Lipman DJ (1997) Gapped BLAST and PSI-BLAST: A new generation of protein database search programs. Nucl Acids Res 25:3389-3402.

Alvarez I and Wendel JF (2003) Ribosomal ITS sequences and plant phylogenetic inference. Mol Phyl Evol 29:417-434.

Baldwin BG, Sanderson MJ, Porter JM, Wojciechowski MF, Campbell CS and Donoghue MJ (1995) The ITS region of nuclear ribosomal DNA: A valuable source of evidence on angiosperm phylogeny. Ann Miss Bot Gard 82:247-277.
Baltisberger M (1991) Cytological investigations of some Greek plants. Flora Medit 1:157-173.

Bechi N and Garbari F (1994) Intraspecific variation and taxonomic aspects of some plants from Apuan Alps (Tuscany, Italy). Flora Medit 4:213-225.

Bechi N, Miceli P and Garbari F (1997 (1996)) Indagini biosistematiche sulla flora apuana, VI contributo: Risultati conseguiti e problemi aperti. Atti Soc Tosc Sc Nat Pisa Mem ser B 103:35-42.

Brullo S, Guglielmo A, Pavone P and Terrasi MC (1994) Numeri Cromosomici per la Flora Italiana. Inf Bot Ital 26:200-213.

Daushkevich JV, Alexeeva TV and Pimenov MG (1991) IOPB chromosome data 3. Intern. Organiz Plant Biosystematists Newsletter 17:8-9.

Downie SR and Katz-Downie DS (1996) A molecular phylogeny of Apiaceae subfamily Apioideae: Evidence from nuclear ribosomal DNA internal transcribed spacer sequences. Amer Journ Bot 83:234-251.

Downie SR, Ramanath S, Katz-Downie DS and Llanas E (1998) Molecular systematics of Apiaceae subfamily Apioideae, Phylogenetic analyses of nuclear ribosomal DNA internal transcribed spacer and plastid $\mathrm{rpoC} 1$ intron sequences. Amer Journ Bot 85:563-591.

Downie SR, Plunkett GM, Watson MF, Spalik K, Katz-Downie DS, Valiejo-Roman CS, Terentieva EI, et al. (2001) Tribes and clades within Apiaceae subfamily Apioideae: The contribution of molecular data. Edinb Journ Bot 58:301-330.

Downie SR, Hartman RL, Sun F-J and Katz-Downie DS (2002) Polyphyly of the spring-parsleys (Cymopterus): Molecular and morphological evidence suggests complex relationships among the perennial endemic genera of western North American Apiaceae. Can Journ Bot 80:1295-1324.

Downie SR, Katz-Downie DS and Spalik K (2000a) A phylogeny of Apiaceae tribe Scandiceae: Evidence from nuclear ribosomal DNA internal transcribed spacer sequences. Amer Journ Bot 87:76-95.

Downie SR, Katz-Downie DS and Watson MF (2000b) A phylogeny of the flowering plant family Apiaceae based on chloroplast DNA rpl16 and rpoC1 intron sequences: Towards a suprageneric classification of subfamily Apioideae. Amer Journ Bot 87:273-292.

Doyle JJ and Doyle JL (1990) Isolation of plant DNA from from fresh tissue. Focus 12:13-15.

Drude CG (1898) Umbelliferae. In: Engler A and Prantl K (eds) Die Naturlichen Planzenfamilian. 3rd edition. Wilhelm Engelmann, Leipzig, pp 63-128, 129-250.

Eddouks M, Lemhadri A and Michel J-B (2004) Caraway and caper: Potential anti-hyperglycaemic plants in diabetic rats. Journ Etnopharm 94:143-148.

Favarger C (1973) Cytotaxonomie de quelques Orophytes des Abruzzes. Acta Bot Acad Scient Hungarica 19:81-92.

Felsenstein J (1981) Evolutionary trees from DNA sequences: A maximum likelihood approach. Journ Mol Evol 17:368-376.

Felsenstein J (1985) Confidence limits on phylogenies: An approach using the bootstrap. Evolution 39:783-791.

Garbari F (1970) Aspetti citotassonomici del contingente endemico apuano. I. Lavori Soc Ital Biogeogr n ser 1:192-201.

Hiroe M (1979) Umbelliferae of World. Ariake Book Company, Tokyo, $2128 \mathrm{pp}$.

Huelsenbeck JP and Ronquist F (2001) MrBayes: Bayesian inference of phylogenetic trees. Bioinformatics 17:754-755. 
Huelsenbeck JP, Larget B, Miller RE and Ronquist F (2002) Potential applications and pitfalls of bayesian inference of phylogeny. Syst Biol 51:673-688.

Katz-Downie DS, Valiejo-Roman CM, Terentieva EI, Troitsky AV, Pimenov MG, Lee B and Downie SR (1999) Towards a molecular phylogeny of Apiaceae subfamily Apioideae: Additional information from nuclear ribosomal DNA ITS sequences. Plant Syst Evol 216:167-195.

Kiehn M, Vitek E and Dobe C (2000) New Counts n. 41-82, in different genera. In: Dobe $\mathrm{C}$ and Vitek E (eds) Documented Chromosome Number Checklist of Austrian Vascular Plants. Verlag des Naturhistorischen Museums Wien, Vienna, pp 41-82.

Kimura M (1980) A simple method for estimating evolutionary rates of base substitutions through comparative studies of of nucleotide sequences. Journ Mol Evol 16:111-120.

Kondo K, Terabayashi S, Okada M, Yuan C and He S (1996) Phylogenetic relationships of medicinally important Cnidium officinale and Japanese Apiaceae based on rbcL sequences. Journ Plant Res 109:21-27.

Kour K, Hamal IA and Gupta SK (1992) Chromosomal variability in Scaligeria stewartiana (Nasir) E. Nasir. Journ Cytol Genet 27:43-45.

Langenberger MW and Davis AR (2002a) Honey bee pollen foraging in relation to flowering phenology of biennial caraway (Carum carvi L.). Can Journ Plant Sci 82:203-215.

Langenberger MW and Davis AR (2002b) Temporal changes in floral nectar production, reabsorption and composition associated with dichogamy in annual caraway (Carum carvi, Apiaceae). Amer Journ Bot 89:1588-1598.

Loeve A and Loeve D (1982) IOPB chromosome number reports LXXVI. Taxon 31:83-587.

Nazarova E and Ghukasyan A (2004) Chromosome Numbers of Flowering Plants of Armenian Flora. Gabrielian E (ed), Institute of Botany, National Academy of Sciences of Armenia, Yerevan, $171 \mathrm{pp}$.

Nemeth E (1998) Caraway: The genus Carum. Harwood Academic Publishers, Amsterdam, 195 pp.

Nylander JAA (2004) MrModeltest 2.0. Program distributed by the author. Evolutionary Biology Centre, Uppsala University, Uppsala.

Pignatti S (1982) Flora d'Italia. v. 2. Edagricole, Bologna, 732 pp.

Pimenov MG and Leonov MV (1993) The genera of the Umbelliferae: A nomenclator. Royal Botanical Garden, Kew, $156 \mathrm{pp}$.

Ruíz de Clavijo E (1990) Números cromosomáticos de plantas occidentales, 619-630. Anal Jard Botán Madrid 47:431-437.

Sehgal CB and Syed Abbas N (1994) Somatic embryogenesis and plant regeneration from hypocotyl tissue of Trachyspermum ammi (L.) Sprague. Phytomorph 44:265-271.

Sheidai M, Ahmadian P and Poorseyedy S (1996) Cytological studies in Iran Zira from three genera: Bunium, Carum and Cuminum. Cytologia 61:19-25.
Simmons MP and Ochoterena H (2000) Gaps as characters in sequence-based phylogenetic analyses. Syst Biol 49:369-381.

Spalik K, Reduron J-P and Downie SR (2004) The phylogenetic position of Peucedanum sensu lato and allied genera and their placement in tribe Selineae (Apiaceae, subfamily Apioideae). Plant Syst Evol 243:189-210.

Stepanov NV and Muratova EN (1995) Chromosome numbers of some taxa of higher plants of Krasnoyarsk territory. Botan urn 80:114-116.

Swofford DL (1998) PAUP 4.0b1*. Phylogenetic Analysis Using Parsimony (*and Other Methods). Version 4. Sinauer Associates, Sunderland, USA.

Tan K and Sorger F (1986) Even more taxa from South and Eastern Anatolia I. Plant Syst Evol 154:111-129.

Templeton AR (1983) Phylogenetic inference from restriction endonuclease cleavage site maps with particular reference to the evolution of humans and the apes. Evolution 37:221244.

Thompson JD, Higgins DG and Gibson TJ (1994) CLUSTAL W: Improving the sensitivity of progressive multiple sequence weighting, positions-specific gap penalties and weight matrix choice. Nucl Acids Res 22:4673-4680.

Tutin TG (1968) Carum L. In: Tutin TG, Heywood VH, Burgess NA, Moore DM, Valentine DH, Walters SM and Webb DA (eds) Flora Europaea 2. Cambridge University Press, Cambridge, pp 354.

Valiejo-Roman CM, Pimenov MG, Terentieva EI, Downie SR, Katz-Downie DS and Troitsky AV (1998) Molecular systematics of Umbelliferae: Using nuclear rDNA internal transcribed spacer sequences to resolve issues of evolutionary relationships. Bot Zhurn 83:1-22.

Valiejo-Roman CM, Terentieva EI, Samigullin TH and Pimenov MG (2002) Relationships among genera in Saniculoideae and selected Apioideae (Umbelliferae) inferred from nrITS sequences. Taxon 51:91-101.

Vasil'eva MG, Alexeeva GV and Pimenov MG (1994) Geographical variation of chromosome numbers in thin-rhizomatous species of Aegopodium (Umbelliferae). Bot hurn 79:27-31.

Vasil'eva MG, Kljujkov EV and Pimenov MG (1985) Karyotaxonomic analysis of the genus Bunium (Umbelliferae). Plant Syst Evol 149:71-88.

Vasil'eva MG, Daushkevich JV, Alexeeva TV and Pimenov MG (1993) IOPB chromosome data. 5 International Organization of Plant Biosystematists, Newsletter 20:7-9.

Verlaque R and Filosa D (1992) Mediterranean chromosome number reports 2 (107-117). Flora Medit 2:264-272.

Wolff H (1927) Umbelliferae - Apioideae - Ammineae - Carinae, Ammineae novemjugatae et genuinae. In: Engler A (ed) Das Pflanzenreich; H. 90 (IV. 228). Engelmann, Leipzig, pp 167.

Young ND and Healy J (2003) GapCoder automates the use of indel characters in phylogenetic analysis. BMC Bioinform $4: 6$.

Associate Editor: Louis Bernard Klaczko 